\title{
Human Resource Management Practices and Firms Performance in Bangladesh: An Empirical Study on Pharmaceutical Industry
}

\author{
Serena Aktar ${ }^{1}$, Md. Shoriful Islam ${ }^{2}$, Sayed Mohibul Hossen ${ }^{3}$ \\ ${ }^{1}$ Department of Business Administration, Northern University Bangladesh \\ ${ }^{2}$ Department of Business Administration, Northern University Bangladesh \\ ${ }^{3}$ Department of Business Administration, Northern University Bangladesh
}

\begin{abstract}
This research work has been conducted in the field of human resource management (HRM), more specifically on firm performance. The aim of the study is to show the relationship between HRM practices and firms performance of pharmaceutical industry in Bangladesh. It is assumed that HRM practices could positively influence profitability and growth and depressingly bias employee turnover. The primary data were collected using structured questionnaire sent to employees of different departments having different job status of some pharmaceutical companies in Bangladesh. Secondary data were collected from annual reports of the selected companies for measuring and finding out their performance. The paper has tried to elucidate the role of HRM practices and to test the relationship among the variables indicating that HRD has a relationship with performance like inventory turnover, total assets turnover, net profit margin, gross profit margin etc. It is found that HRM practices enhance performance of the pharmaceutical firms in Bangladesh.
\end{abstract}

\section{Keywords: HRM Practice, Firm's Performance, Pharmaceutical Industry} JEL Classification Code: M120

\section{INTRODUCTION}

$\mathrm{T}$ HE concept of HRM became popular in the early 1980s; since then there has been increasing interest in the academic concept as well as in the research area. Early models of HRM were largely conceptual and not based on substantial empirical evidence for their validity (Beer, Spector, Lawrence, Miles \& Walton,1984; For burn, Tichy \& Devanna,1984; Guest,1989). The 1990s saw a substantial amount of empirical research carried out to find evidence on the link between HRM practices and performance. In recent years much of the research work could, in fact, find statistical evidence for an association between HRM practices and resulting performance (e.g. Arthur, 1994; Huselid, 1995; Ichniowski, Shaw \& Prennushi, 1997). Recently human resources have been recognized as an important source of continued competitive advantage. A number of researchers examining the relationship between HRM and firm performance have taken a micro approach investigating single HRM practices such as staffing, training, goal-setting, compensation, and so forth, and the effects of those practices on organizations' outcomes.

In this millennium, the role of human resources remains important to organizations. In spite of this evidence, many organizations are slow in adopting those practices that were found to contribute to organizational success. This situation is found not only in the plantation sector (Bawa, 2000), but also in manufacturing sector.
Effective use of human resources leads to a number of consequences like helping the firm to achieve its objectives, increasing employees' job satisfaction, providing the firm with well-trained and motivated employees and developing quality of work life which makes employment personally and socially desirable. (Khan, 2007)

An effective and competitive human resource is the key to the strength of organizations in facing the challenges of business today. Such type of human resource will produce quality and productive individuals that will eventually minimize the problems related to human resources such as job dissatisfaction, absenteeism, or turnover of employees (Daud, 2006).

Pharmaceutical companies design and produce pharmaceutical products, including drugs, medical products and equipments (for example cardiovascular or laser equipment), not for open sale only but also as prescriptiononly products which are then made available to doctors, nurses, hospitals and pharmacists. Human resources policy is the most vital elements of corporate policy since it guides recruitment, selection, orientation, training and placement of personnel. In fact, this policy is concerned with proper use of human resources required for undertaking activities in order to achieve corporate goals and objectives. This is the age of change. Continuous changes have been occurring in the areas of science and technology. Yesterday's product becomes out of date today and so it will be with tomorrow's technicians, technologists, 
scientists, supervisors, workers and researchers. Therefore, a sensible entrepreneur should make proper practices of human resources to keep and develop the firm's employees as well as the operational performance.

\section{ObJectives of the Study}

The main objective of this study is to examine the relationship between human resource practices and firms' performance in pharmaceutical industry in Bangladesh. More specifically the study is intended to achieve the following objectives:

1. To identify the HRM practices in pharmaceutical industry in Bangladesh,

2. To compare the financial performance of selected pharmaceuticals.

3. To evaluate the impact of HRM practices on the firm's performance.

\section{Literature REVIEW}

A number of authors have explored the links between individual HR practices and corporate financial performance. Lam and White (1998) reported that firms' HR orientations (measured by the effective recruitment of employee, above average compensation, and extensive training and development) were related to return on assets, growth in sales, and stock values.

HRM function is increasingly important in shaping a new organization in which the quality and commitment of people are keys to survival. According to Gordon (2000) each aspect of HRM needs to be reassured; but none is more pivotal or difficult than Performance Management System. Employees at all levels experience a need to know clearly what they should be doing and what is expected of them in terms of quantity and quality of output.

Performance appraisal should lead to identification of training and development needs. It also creates a new basis for improvement and development. Performance Management

System provides some of the essential components of effective motivational strategies. In particular feedback that permits an employee to learn how well he or she is performing is of necessity. The system also provides relevant information required for validating selection methods.

Wright and Mcmahan (1992) defined the planned HR deployments and activities intended to enable to achieve its goals. Boselie et. al. (2005) defined that HR deployment reflects the central assumptions behind the conceptualization of what HRM is and does: namely, that it responds accurately and effectively to the organization's environment and completement other organizational systems and contingencies. Boselie and Deitz (2003) and Katou and Budhwar (2006) report that there are commonalities and also contradictions in HRM and performance research (Wall and Wood, 2005: Wright and Boswell, 2002).
Boswell (2002) carried out a study to investigate a relationship between HRM practices and corporate performance that may probably serve as the seminal work in this area. This approach has also been cited maximum. The outcome of this study was described through the observation that high-involvement of HRM practices to be strongly and positively linked to various measures of organizational performance. Delaney and Hselid (1996) found that HRM practices (selection, training compensation, and so on) had positive effect on the organizational performance.

\section{Methodology}

For this study, two types of data have been collected and all of them were collected from some listed firms in the Dhaka Stock Exchange. Four profitable and renowned pharmaceutical companies namely Square Pharmaceuticals Company Ltd., Beximco Pharmaceuticals Company Ltd., Ibn Sina Pharmaceuticals Company Ltd. and Renata Pharmaceuticals Company Ltd. were selected for the study. Five years' annual reports of the companies were studied to find out their performance (especially financial). The reason for choosing these sources is primarily due to the better reliability of their financial statement. The primary data have been collected through a structured questionnaire where open and closed ended options have been considered. In total eighty employees, twenty from each company have been selected. The status of each respondent is officer or above but not manager. Five Point Likert-Scales has been used to analyze the primary data.

\section{THE CONCEPTUAL FRAMWORK}

\subsection{HRM Practices}

HRM practices refer to organizational activities directed at managing the pool of human resources and ensuring that the resources are employed towards the fulfillment of organizational goals (Schuler \& Jackson, 1987; Schuler \& MacMillan, 1984). The primary HRM and HRD functions can be presented here with the help of the following human resources wheel.

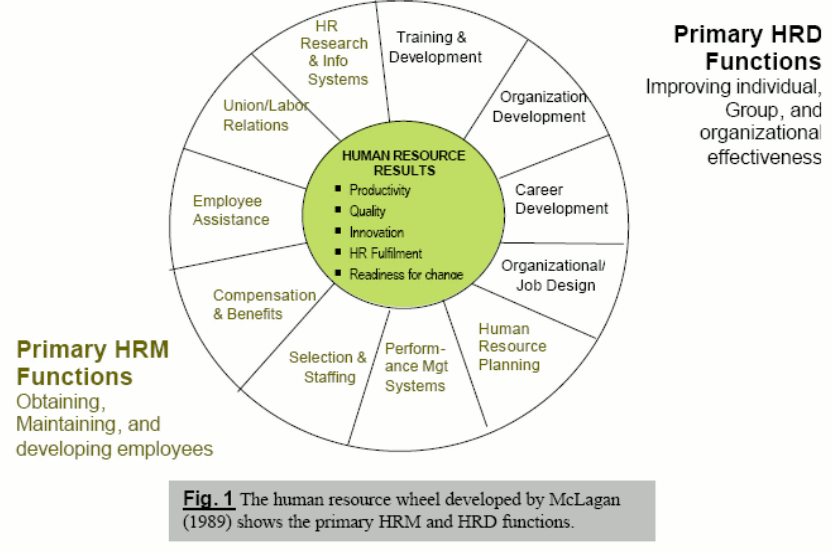




\subsection{Firm Performance}

For the present study, firm performance refers to inventory and total assets turnover, net and operating profit margin and earning per share and all these are considered as the prime indicators to evaluate the selected companies.

\subsection{Inventory Turnover:}

Inventory Turnover Ratio is an efficiency ratio and it measures the number of times, on an average, the inventory is sold and replaced during the fiscal year. A low value of the inventory turnover ratio is a signal of inefficiency, since inventory usually has a rate of return of zero. It also implies either poor sales or excess inventory. A high inventory turnover ratio, on the other hand, can indicate better liquidity; but it can also indicate a shortage or inadequate inventory levels, which may lead to a loss in business.

\subsection{Operating Profit Margin}

The operating profit margin ratio indicates the amount of profit a company makes after making payment for the variable costs for production such as wages, raw materials, etc. It is expressed as a percentage of sales and it shows the efficiency of a company controlling the costs and expenses associated with business operations. It also illustrates how efficiently the managers of a firm are using business operations to generate profit.

\subsection{Net Profit Margin}

Net Profit Margin tells exactly how the managers of operations of a business are performing. This result/margin compares the net income of a firm with the total sales achieved.

\subsection{Return on Total Assets}

Return on total assets is a ratio that measures a company's earnings before interest and taxes (EBIT) against its total net assets. The ratio is considered as an indicator of how effectively a company is using its assets to generate earnings before contractual obligations that have to be paid.

\subsection{Total Assets Turnover}

The total asset turnover ratio measures the ability of a company to use its assets to generate sales. The total asset turnover ratio considers all assets including fixed assets, like plant and equipment, as well as inventory and accounts receivable.

\subsection{Earning Per Share (EPS)}

In the present work EPS has been calculated by taking a company's net earnings and dividing it by the number of outstanding shares of the stock the company possesses. In order to make earning comparison more useful across the companies, EPS is considered as the most effective indicator.

TABLE-1: STATISTICAL FINDINGS OF HRM PRACTICES
\begin{tabular}{|l|c|c|c|c|c|c|c|c|c|c|c|c|}
\hline \multicolumn{1}{|c|}{ Tools } & \multicolumn{3}{|c|}{ Weighted Average } & \multicolumn{3}{c|}{ Standard Deviation } & \multicolumn{3}{c|}{ Rank } \\
\hline 1 & 2 & 3 & 4 & 5 & 6 & 7 & 8 & 9 & 10 & 11 & 12 & 13 \\
a & b & c & d & a & b & C & d & a & b & c & d \\
\hline Recruitment and Selection & 48.75 & 50.5 & 53 & 53.25 & 3.40 & 1 & 3.65 & 1.71 & 4 & 3 & 2 & 1 \\
\hline Training and Development & 46.25 & 45.63 & 47.88 & 51.38 & 3.58 & 3.54 & 2.47 & 1.41 & 3 & 4 & 2 & 1 \\
\hline Performance Appraisal & 44.67 & 33.83 & 41.83 & 52.5 & 3.56 & 7.76 & 3.49 & 1.05 & 2 & 4 & 3 & 1 \\
\hline Rewards & 36 & 31 & 43.67 & 52 & 4.36 & 10.44 & 2.89 & 1.70 & 3 & 4 & 2 & 1 \\
\hline Autonomy & 48.6 & 40.8 & 43.2 & 49.75 & 3.21 & 8.73 & 8.99 & 4.27 & 2 & 4 & 3 & 1 \\
\hline Participation & 44.6 & 38.5 & 43.4 & 51.2 & 5.18 & 6.39 & 4.83 & 2.17 & 2 & 4 & 3 & 1 \\
\hline Total & 268.87 & 240.26 & 272.98 & 310.1 & & & & & 3 & 4 & 2 & 1 \\
\hline
\end{tabular}

Note: A scale like $5=$ strongly agree, $4=$ agree, $3=$ neither agree nor disagree, $2=$ disagree, $1=$ strongly disagree is used.

Here 'a' for Beximco Pharmaceutical Company Ltd., 'b' for Ibn Sina Pharmaceuticals Company Ltd., ' $c$ ' for Square Pharmaceuticals Company Ltd. and ' $d$ ' for Renata Pharmaceuticals Company Ltd

Source: Field Survey, April-July: 2011

Table 1 presenting data on HRM Practices of Square Pharmaceuticals Company Ltd., Beximco Pharmaceuticals Company Ltd., Ibn Sina Pharmaceuticals Company Ltd. and Renata Pharmaceuticals Company Ltd. Column 2 reveals that the weighted average of recruitment and selection is 48.75 (SD 3.40 ) being the highest among all of the functions. On the other hand the weighted average of reward is 36 ( $\mathrm{SD}=4.36>3.21$ ) which is the lowest weighted average among all of them. But the standard deviation of participation is the highest.

Table 1 column 3 shows that the weighted average of recruitment and selection of the Ibn Sina Pharmaceuticals Company Ltd is the highest $(=50.50)$ having its standard deviation 1 . The weighted average of rewards of the company is 31 which is the lowest value among all functions' weighted averages. Its standard deviation is the highest $(=10.44)$ meaning that the rewarding practice of this company is not very good and fair.

Column 4 of Table 1 show that after recruitment and selection, the training and development of an employee of Square Pharmaceutical Company Ltd. gets second preference as is clear through the value of its weighted average of 47.88 (standard deviation $=2.47$ ). This value of the standard deviation is the lowest among all. It is mentioned that reward of this company is not bad as is shown through its weighted average position $(=3 \mathrm{rd})$ and its standard deviation (=2.89) which is lower than that for recruitment and selection function. Though the weighted average of performance appraisal is the lowest but its standard deviation is not high $(3.49<3.65<4.83<8.99)$ where the standard deviation of autonomy is the highest (8.99) meaning that its distribution is not fair.

Column 5 of Table 1 demonstrates that the weighted average of performance appraisal of the Renata Pharmaceuticals Company Ltd. is 51.38 having its standard deviation 1.05. This value of the standard deviation is the lowest among all other standard deviation values of this company. This means that the practice of performance appraisal is almost fair. The total weighted average (310.08> 272.98>268.87>240.26) of the Renata Pharma- 
ceuticals Company Ltd is highest that means the performance of HRM practices are comparatively better among all of the company.

TABLE-2: PERFORILANCE INDICATORS AND COMPARATIVE ANALYSIS:

\begin{tabular}{|c|c|c|c|c|c|c|c|c|c|c|c|c|}
\hline $\begin{array}{l}\text { Variables } \\
\end{array}$ & \multicolumn{4}{|c|}{ Average } & \multicolumn{4}{|c|}{ Standard Deviation } & \multicolumn{4}{|c|}{ Rank } \\
\hline 1 & 2 & 3 & 4 & 5 & 6 & 7 & 8 & 9 & 10 & 11 & & 13 \\
\hline & a & b & C & D & a & b & c & d & A & b & c & d \\
\hline Inventory Turnover (times) & 1.24 & 9.18 & 2.69 & 1.78 & 0.17 & 2.53 & 0.21 & 0.25 & 4 & 1 & 2 & 3 \\
\hline $\begin{array}{l}\text { Operating Profit } \\
\text { Margin (\%) }\end{array}$ & 21.13 & 5.28 & 20.44 & 22.19 & 2.47 & 1.64 & 1.62 & 2.08 & 2 & 4 & 3 & 1 \\
\hline Net Profit Margin (\%) & 12.73 & 4.24 & 15.64 & 13.46 & 1.81 & 1.08 & 0.94 & 1.36 & 3 & 4 & 1 & 2 \\
\hline Retum on Assets (\%) & 3.64 & 8.20 & 12.80 & 14.73 & 0.61 & 1.95 & 1.34 & 1.01 & 4 & 3 & 2 & 1 \\
\hline Total Assets Tumover & 0.28 & 1.94 & 0.82 & 1.10 & 0.03 & 0.16 & 0.06 & 0.12 & 4 & 1 & 3 & 2 \\
\hline $\begin{array}{l}\text { Eaming Per Share } \\
\text { (Amount in Tk.) }\end{array}$ & 21.01 & 38.63 & 159.71 & $\begin{array}{c}249.9 \\
7\end{array}$ & 1.32 & 12.8 & 43.2 & $\begin{array}{c}13 . \\
19\end{array}$ & 4 & 3 & 2 & 1 \\
\hline
\end{tabular}

Source: Calculated value of studied companies based on last five years (20052009) financial report.

Here 'a' for Beximco Pharmaceutical Company Ltd., 'b' for Ibn Sina Pharmaceuticals Company Ltd., ' $c$ ' for Square Pharmaceuticals Company Ltd. and ' $\mathrm{d}$ ' for Renata Pharmaceuticals Company Ltd.

Table 2 presenting data on financial performance of Square Pharmaceuticals Company Ltd., Beximco Pharmaceuticals Company Ltd., Ibn Sina Pharmaceuticals Company Ltd. and Renata Pharmaceuticals Company Ltd.

According to above mentioned table (Table 02), it is clearly observed that among the four selected companies, IbnSina Pharma's inventory turnover (table 2 column 3) was the most frequent one and in this regard Square Pharma was in the second position. But according to the calculated standard deviation, Square Pharma's inventory management was more stable than that of Ibn-Sina Pharma and the lowest deviation observed here was for Beximco in spite of lower value of the average. Renata acquired the third position based on its inventory management performance.

Table 2 also shows the operating profit margin position of the selected firms. Renata Pharma tops the list (table 2 columns 5) expressing effectiveness of its operating cost control policy like salaries, wages, power, rent, maintenance costs, directors' fee etc. The lowest position is for Ibn-Sina Pharma (table 2 column 3 ) and it is almost one fourth of that of other firms. From its financial statements, negative growth is identified which signals firm's lower operational efficiency comparatively. Square Pharma is in the third position based on this variable but showing an attractive stability of operating profit margin comparing with other companies. Among the four companies, highest instability has been detected for Beximco Pharma.

The given results in the table 2 have come from the calculated margin for the year 2005 to 2009. It may be observed that the net profit performance of Square Pharma places the company at the highest position (15.64\%) among the selected four companies and lowest position is dictated for Ibn-Sina Pharma (4.24\%) which is almost one-fourth of the former. Based on the standard deviation (SD) results as above, it is also clear that Square Pharma is doing their performance with greater stability compared with others. The value of standard deviation is almost 50\% lower than that of Beximco Pharma having the highest S.D. This is due to the efficient performance of finance department's employees in terms of attractive short term investment of their earnings and effective control of its financial expenses. Renata and Beximco also show very good performance in this respect.

The above table (table 2) clearly depicts that Renata Pharmaceuticals ensures the most effective uses of its assets; the second position is hold by Square Pharma. As a large company, Beximco has failed to generate an attractive return from its total assets which is almost one fourth of that of Renata. Based on the calculated standard deviation it can also be said that return stability of Renata is quite satisfactory. Though, the result of S.D. is the lowest for Beximco which proves stability at the same time poor return generating ability of this firm. Return generating ability with involved assets of Ibn-Sina Pharma is not so attractive and it is lower than that of Renata and Square.

The total asset turnover of Ibn-Sina Pharma from table 2 shows a comparatively good performance (1.94 times) and the lowest turnover is observed for Beximco Pharma (0.28 times). Based on the calculated result it can be said that Ibn-Sina Pharma is using its assets with highest efficiency for generating sales. Renata is at the second position in this respect. Beximco's turnover is poor which indicates poor performance of assets utilization in generating sales compared with other three companies. This firm's S.D. of total assets turnover also expresses that its performance of the last five years was not so deviated and thus no growth could be observed.

Table 2 indicates that the earning per share of Renata Pharma is highly attractive (average Tk. 249.97). In this respect Square Pharma is in the second position and Beximco Pharma has attained the last position (average only Tk. 21.01). It may be said that after meeting all types of expenditures and fixed charges, Renata and Square are able to ensure very satisfactory earnings for its common stockholders and it indicates their overall operational efficiency and highest level performance among the selected four companies.

\section{Comparative Analysis of Weighted Average of All Variables for Selected COMPANIES}

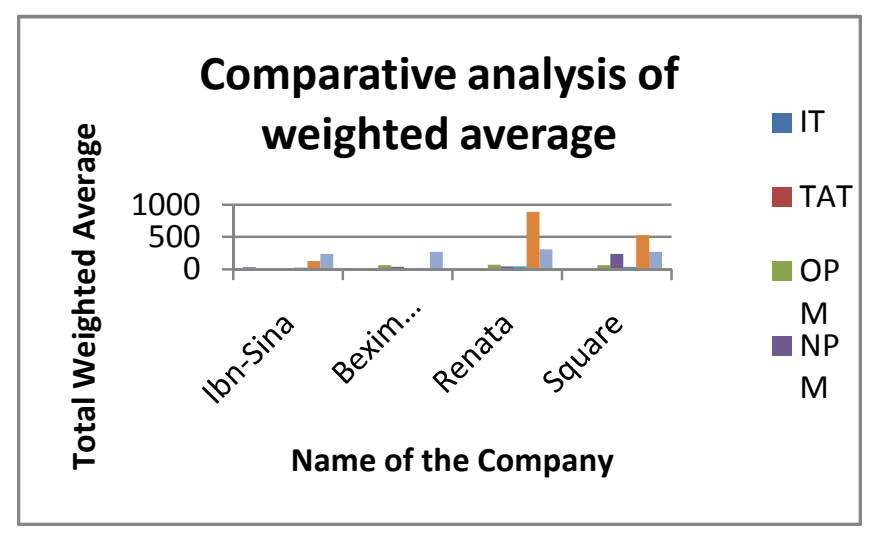


From the above graph, it is observed that, total weighted average of HRM practices of Reneta Pharmaceutical Company Ltd is maximum compare to that of the other selected companies. Among six indicators of firm performance, three most important variables of the company show maximum weighted average values. Of the remaining variables, MPM and TAT of the company are captured the second position. Total weighted average of all the variables for Ibn Sina Pharmaceutical Company Ltd. show the lowest values, excepting two performance indicators e.g. IT and TAT. Based on the above scenario, it can be said that, firm's financial performance is highly affected by HRM practices at the firm level in Bangladesh.

\section{CONCLUSION \& RECOMMENDATIONS}

This study describes the significance of HRM practices for human capital development and thus improving firm productivity and financial performance. Primarily, these practices are very much focused to develop employees at all levels of the organization. The success in the pharmaceutical business largely depends on its distribution strength, quality control, good management, good training program, use of modern technology, and product innovation. The evaluation of the pharmaceutical's performance is a complex process involving interaction between the environment, internal operation and external activities. The ultimate objective of the management is to maximize the value of the pharmaceutical's equity share by attaining the optimal mix to return and risk. In this respect management needs to develop a comprehensive plan in order to identify objectives, goals, budgets and strategies that will be consistent with the maximization of the share values.

Performance of pharmaceutical companies depends on the HRM practices of the company. Based on the study, it can be said that, HRM practices have a major impact on the firms' performance. Because, firms which practice HRM system very effectively are doing well in terms of financial as well as overall performance. The practices of HRM functions also vary from company to company; but the performance of those companies also. The weighted average of all the company's recruitment and selection procedures is the highest which means that they select their employees in a proper way whereas they sometimes they ignore participation and autonomy. It is worth mentioning here that the impact of participation and autonomy does not significantly affect the firm's financial performance.

\section{REFERENCES}

[1] Ahmad, Iqbal \& Khalil Md. Ibrahim (2007) "Human Resource Planning in the Banking Sector of Bangladesh: A Comparative Study Between Public and Private Bank", Journal of Business and Administration, Oct.33.

[2] Boselie, P., Dietz, G., and Boon, C.(2005). Commonalities and contradiction in HRM and performance research. Human Resource Management Journal, 15(3):67-94
[3] Delaney, J.T. and Huselid, m.a. 91996).The impact of human resource management practices on perceptions of organizational performance. Academy of Management Journal, 39(4):949-969.

[4] Gerhart, B., Wright, P. M., Mcmahan, G. and Snell, S. A. (2000). Measurement error in research on human resources and firm performance: how much error is there and how does it influence effect size estimates? Personnel Psychology,53(4):803-834.

[5] http://www.ccdconsultants.com/documentation/financialratios/inventory-turnover-ratio-interpretation.html, accessed on 12 September 2011 at 9:30 am.

[6] Khan, A., Awal, (2007) “Human Resource Management” Abir Publication, Banglabazar, Dhaka.

[7] Lam, L.W. and White, L.P.(1998). Human resource orientation and corporate performance. Human Resource Development Quarterly, 9(4):351-364.

[8] Billah, M. Masum, \& Prince, S., Ashiqurrahman (2008), “ Human Resource Management Practices and customer Satisfaction level: A Study on Private Commercial Banks in Bangladesh, Journal of Business and Technology(Dhaka),December -03.

[9] Billah, M. Masum, Prince, S., Ashiqurrahman \& Islam, Shafiqul, (2009) "Human Resource Management Practices and Employee Turnover: A Study on Private Commercial Banks in Bangladesh" Journal of Business and Technology(Dhaka), June-iv

[10] Fischer, Donald E; Ronald J Jordan (1999), Security Analysis and Portfolio Management (6th Edition), New Delhi: Prentice Hall of India Private Limited.

[11] Mostafa, Md., Golam, (2008) “Human Resource Management Practices in the Steel and Engineering Industry of Bangladesh: A comparative Study" Journal of Business and Technology(Dhaka),June-03.

[12] Schuler, R.S. and MacMillan, I.C.(1984). Gaining competitive advantage through HRM Practices, Human Resource Management, 45(3):45456.

[13] Schuler, R.S. and Jackson, S.E.(1987). Linking competitive strategies with human resource management practices. Academy of Management Executive,1(3):207-219.

[14] Wall, T.D. and Wood, S.J.(2005). The Romance of Human Resource Management and Business Performance, and the Case of Big Science, Human Relations, 58 (4): 429-462

[15] Wright, P.M. and Boswell, W.R. (2002). 'Desegregating HRM: a review and synthesis of micro and macro human resource management research'. Journal of Management, 28:3, 247-276.

[16] Wright, P.M. and McMahan, G.C. (1992. Theoretical perspectives for strategic human resource management. Journal of Management, 18(2): 295-320. 